\title{
RESEARCH PAPER \\ EFFECTS OF WEED MANAGEMENT ON THE PREVALENCE OF PINK PINEAPPLE MEALYBUGS IN GHANA
}

\author{
J. W. Tachie-Menson ${ }^{1}$, J. Sarkodie-Addo ${ }^{2} *$ and A.G. Carlson ${ }^{1}$ \\ ${ }^{1}$ Crop Science Department, University of Cape Coast, Cape Coast \\ ${ }^{2}$ Crop and Soil Sciences Department, KNUST, Kumasi \\ *Corresponding author
}

\begin{abstract}
An on-farm experiment was conducted in August 2010 to evaluate the efficacy of various weed management methods used in pineapple cultivation in Ghana in limiting the prevalence of the pineapple mealybugs and their tending ants. The experiment was a 5 X5 Latin Square design with 5 replications. The weed management methods (the treatments) imposed was weedy check (no weed control), manual weeding by hoeing, synthetic herbicide application, plastic mulch + manual weeding and plastic mulch + synthetic herbicide application. The field was ploughed and harrowed and plots each measuring $2 \mathrm{~m}$ by $2.7 \mathrm{~m}$ were marked out. Suckers obtained from a nearby commercial farm were planted at the spacing of $90 \times 60 \times 25 \mathrm{~cm}$. Fertilizer was applied at the recommended rate and pests were controlled by spraying with both fungicide and an insecticide. Data taken from the inner 20 plants of each plot were: time taken for weeds to re-emerge, weed species that emerged, weed population and weight and presence of mealybugs on the fruits and in the root zone. The result showed that, time of weed re-emergence was longest in the plastic mulch + herbicide treatment, whilst re-emergence was fastest in the manual weed control treatment. Guinea grass (Panicum maximum) belonging to the Poaceae family re-emerged on all treatment plots. The plastic mulch + herbicide treatment was able to control all broadleaved weeds, whilst most broadleaved and grass species re-emerged from the manual weeding treatment throughout the period. Weed population, weed dry weight and number of weed species re-emerged, were all significantly lower in the plastic mulch + herbicide treatment than in all other treatments but were greatest in the manual weed treatment. The results indicated that weed control efficiency of 90.6 , 80.2, 73.4 and 69.2\% in the plastic mulch + herbicide, plastic mulch + manual control, herbicide alone and the manual control over the weedy check, respectively. However, mealybug populations were not affected by the weed management methods employed, although all treatment effects were significantly greater than weedy check. The ability of the treatments to reduce mealybug populations on both the fruits and the root zone might be that during weed control, the mealybugs were exposed to predators that feed on them or that weed control dislodges their tending ants which subsequently limit their spread. This study affirms that proper weed control would reduce mealybug population and minimize the damage to fruits.
\end{abstract}

Keywords: pineapple, mealy bug, weed control efficiency, plastic mulch, guinea grass 


\section{INTRODUCTION}

Pineapple is a very important fruit crop across the globe, usually eaten fresh or processed into fruit juice. It is the third most important tropical fruit in world production after banana and citrus (Rohrbach et al., 1988). Until 2006, pineapple was the most important horticultural non-traditional export commodity in Ghana, fetching the country some US\$ $13,475,000$ from a total of 40,456tons exported in that year (SRID, 2007).

Pineapple production in Ghana is, however, limited by a number of pests and diseases. Prominent among them are the various species of weeds and the Pink Pineapple Mealybug which is known to be the cause of the Pineapple Mealybug Wilt. The Pink Pineapple Mealybug is believed to be transferred from surrounding weeds to the pineapple fields by their tending ants and/or wind. The wilt has been a continuing problem in pineapple production for over 90 years (Rorhbach et al., 1988) and continues to cause the most serious type of damage, making it the principal cause of pineapple crop failure (Mau and Kessing, 2007).

Despite many suggested control measures for the pineapple mealybug complex, very little has been achieved in attempts to control it. Morton (1987) observed that it was difficult to control the mealybug because it lives on several plants including Hilo grass, nutgrass, Guinea grass, banana, citrus, coffee, cotton, Euphorbia, Gliricidia, and Hibiscus. Weed management therefore, has become an essential component in its control. Weed management, however, in pineapple fields comes in different methods including hand weeding with hoe and other simple implements; mulching with organic (plant materials) and inorganic sources (plastic film) and the use of herbicides (Akobundu, 1987). The objectives of this study were (i) to evaluate the efficiencies of common weed management strategies in pineapple cultivation, (ii) to determine the effect of the various weed management meth- ods on pineapple fields on mealybug population densities and (iii) to determine the profitability of production under the various weed management strategies.

\section{MATERIALS AND METHODS Study Area}

The experiment was carried out on-farm at Bomarts Farms located in the northern part of the Ga East Municipality of the Greater Accra Region. The field lies in the Coastal savanna agro-ecological zone, with the natural vegetation made up mainly of shrubs and grasses. The area has a total annual rainfall of between $1200 \mathrm{~mm}$ and $1400 \mathrm{~mm}$ in two rainy seasons starting from April and July (major season) and September and late October (minor season). Temperatures of the area are high and uniform around $20^{\circ} \mathrm{C}$. Soil analysis conducted at the beginning of the experiment described the soil as mainly sandy loam with $\mathrm{pH}$ of 5.0 , bulk density of 1.37 and organic matter content $0.37 \%$. The soil has been classified as Eutric Plinthosol (FAO, 1990).

\section{Treatments and Experimental Design}

The treatments investigated were weedy check (no weed control), manual weeding (only), synthetic herbicide (bromacil + diuron), plastic mulch + manual weeding and plastic mulch + synthetic herbicide. The experiment was arranged in a $5 \times 5$ Latin square design with 5 replications. Each of the 25 experimental plots comprised $2.7 \times 2 \mathrm{~m}$. Three ridges, each of width $90 \mathrm{~cm}$ and length $175 \mathrm{~cm}$, were constructed and covered with plastic film in the plastic mulch treatments. Four hundred grams pineapple suckers obtained from the sucker plots of Bomarts Farms were used for the experiment. These were planted in three double rows on each plot, with seven plants per row to give a total of 42 plants per plot at a spacing of $90 \mathrm{~cm} \times 60 \mathrm{~cm} \times 25 \mathrm{~cm}$. Planting was done on $27^{\text {th }}$ August, 2010. Data was collected on the inner 20 plants of each plot.

Ridomil Gold (fungicide) at $0.4 \mathrm{~kg}$ dissolved in 200 litres of water and Dursban (insecticide) at 
$360 \mathrm{ml}$ in 200litres of water was applied 58 days after planting. Fertilizer application was carried out six times before floral induction (forcing) and once after forcing.

The respective weed management practices (treatments for the experiments) were first imposed eight weeks after planting. Subsequently, weed control was carried out on monitored regime. The weedy checks were never weeded until floral induction when the weeds were slashed to aid forcing. Treatments 2 (manual weeding by hoeing) and 4 (plastic mulch+ manual weeding) were weeded four times before floral induction and twice after with a long hoe due to frequent re-emergence of weeds. Treatments 3 (synthetic herbicide) and 5 (plastic mulch+ synthetic herbicide) were sprayed with $500 \mathrm{~g}$ of diuron $+500 \mathrm{~g}$ of bromacil dissolved in 200litres of water with a knapsack sprayer once, since weeds did not re-emerge to warrant re-application.

\section{DATA COLLECTION AND ANALYSIS}

Time taken for weeds to re-emerge: After the first application of weed management methods, the plots were monitored to determine the time taken for weeds to re-emerge. The time was measured in weeks.

Weed species emerged: The weeds which reemerged after treatments application were identified using weed identification manuals and recorded for the various plots. Samples of weeds which could not be easily identified with the handbooks were sent to the Herbarium of the Department of Botany, School of Biological Sciences, University of Cape Coast for identification. The identification was to help determine if the species of weeds which re-emerged would vary with the method of weed control used.

Weed population and weight: A $25 \mathrm{~cm} \times 25 \mathrm{~cm}$ quadrat was used to sample four points at random on each plot to determine the various weed parameters. For each quadrat, the major weed species identified were counted. The weed populations were expressed on per square metre basis. The data was transformed by the square root after a constant figure of 0.5 was added to each of the figures. Analysis was by ANOVA, using the Genstat Statistical Package (GenstatDE3, 2008) and the means separated by the Duncan's Multiple Range Test (DMRT). The means were later back transformed to get the actual means.

The weeds were harvested and oven-dried at $80^{\circ} \mathrm{C}$ until uniform weights were attained. They were then weighed with a top pan balance to determine their dry weight. Due to the huge differences in the figures obtained, the data was transformed using the log (base 10). The transformed figures were analyzed by ANOVA with the Genstat Statistical Package (Genstat DE3, 2008) and the means were separated by the DMRT. The means were later back transformed.

Entomological Data: The number of mealybugs per fruit and in the root zone was estimated at harvest. This was done by first counting the number of mealybugs observed on the harvested fruits and then uprooting five plants in the " $X$ " pattern and estimating the number of mealybugs on roots and leaf bases. The data was transformed by the square root after a constant figure of 0.5 was added to each of the figures. Analysis was by ANOVA, using the Genstat Statistical Package (Genstat DE3, 2008) and the means separated by the DMRT. The means were later back transformed.

Economics of production under the various weed management methods: The cost: benefit analysis was carried out with the help of secondary data obtained from Milani Farms Ltd on the costs of various inputs and services and the selling price of marketable fruits per kilogram. The cost of weed control for each treatment, the percentage of fruits marketable and mean fruit weight obtained from the field experiment were factored into the calculation. 


\section{Sarkodie-Addo et al.}

\section{RESULTS AND DISCUSSION}

Efficacy of weed management methods

Fig. 1 shows the effect of the treatments on the regrowth of weeds. The Plastic mulch + synthetic herbicide treatment was able to suppress weed growth for the longest period, whilst weed re-emergence was fastest in the manual weeding treatment. Treatment differences between the two herbicide treatments were not significant $(p>0.05)$. The herbicide treatments performed better because the pre-emergent herbicide, diuron is reportedly able to suppress weed growth up a year (Anonymous, 2005). This was enhanced by the plastic mulch in the plastic mulch+ herbicide treatment which is able to prevent the germination and emergence of weeds. The manual weeding treatments could not suppress weed growth for long because there was no sustainable measure to prevent germination of weed seeds, although the plastic mulch + manual weeding lasted a bit long because of the mulch. Weed growth in the plastic mulched plots occurred mainly in between the ridges.
The primary aim of weed management is to keep weeds below the economic threshold (Naylor, 2002) for as long as possible, especially during the early growth and fruiting stages. Hence, one major criterion for measuring the effectiveness of a weed management system is the time taken for weeds to reemerge. In the present studies, it was evident that the plastic mulch+synthetic herbicide treatment was the most effective.

Table 1 shows the composition of the reemerged flora. Guinea grass (Panicum maximum) belonging to the Poaceae family was present on all the plots. Apart from this, the only grass species that re-emerged was Paspalum conjugatum in the plastic mulch + herbicide plot. This trend indicated that all treatments were effective in controlling broadleaved weeds. The plastic + manual weeding treatment was effective in the control of all broadleaves except Syndrella modiflora and Tridax procumbens. Apart from controlling Desmodium scorpiurus and Euphorbia hirta, the manual weed-

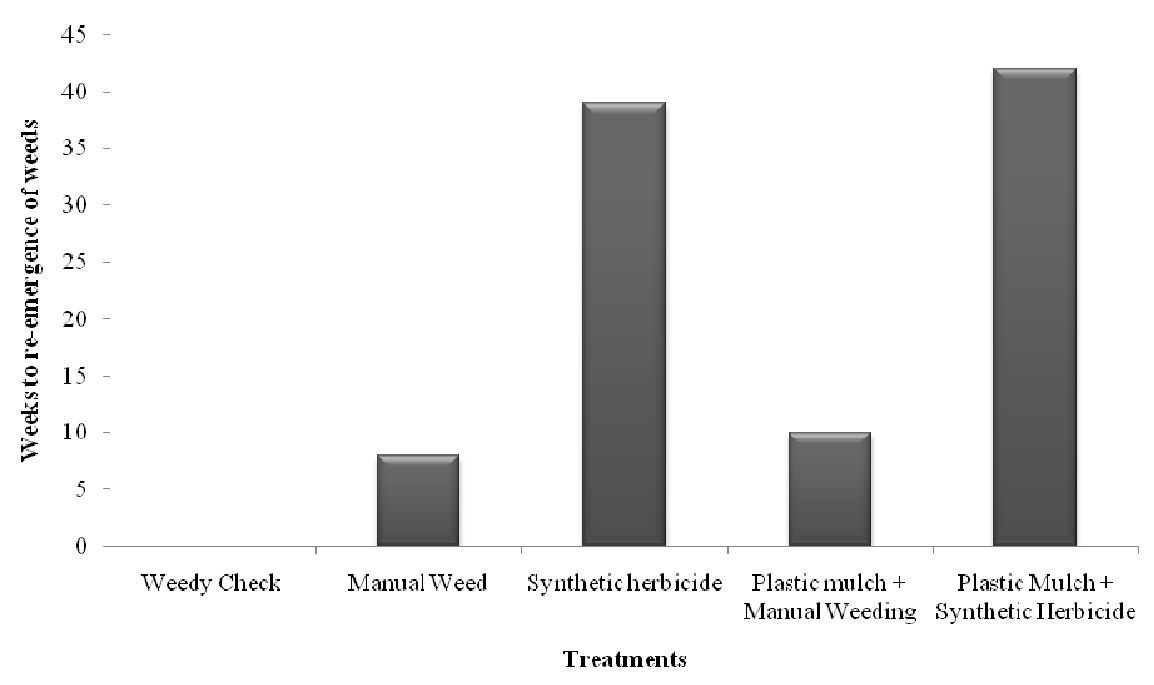

Fig. 1: Weeks to re-emergence of weeds after initial treatment in pineapple fields 
ing treatment was not better than the check on re-emergence of broadleaved species.

It could also be observed that, the re-emerged weed flora was different from the initial flora before the start of the experiment. This trend of weed succession is due to the presence of weed seeds in the soil which had not germinated as a result of unfavourable conditions. Thus, at the onset of the better conditions, the weed seeds could germinate. Panicum maximum however dominated and was present in all the treatments. This is because the initial weed flora before planting was mainly made up of this perennial grass which, by then, had flowered and dispersed a large number of its seeds. The other weed species recorded were possibly part of the weed seed bank on the field.

Weed population density varied with the treatments applied (Table 2). Plastic mulch + synthetic herbicide recorded the least population density of weeds which was significantly different from all other treatments. The difference, as discussed above was due to the persistence of the pre-emergent herbicide, diuron which was applied. Significant differences, however, did not occur between the manually weeded

Table 1: Major weed species recorded on the various treatments in the pineapple fields

\begin{tabular}{|c|c|c|c|}
\hline Treatments & Botanical name of weed & Family & $\begin{array}{l}\text { Growth habit and } \\
\text { morphology }\end{array}$ \\
\hline Weedy Check & $\begin{array}{l}\text { Panicum maximum } \\
\text { Desmodium scorpiurus } \\
\text { Digitaria insularis } \\
\text { Tridax procumbens } \\
\text { Talinum triangulare } \\
\text { Euphorbia hirta } \\
\text { Boerhavia erecta } \\
\text { Syndrella nodiflora } \\
\text { Eragrosti sciliaris } \\
\text { Rynchelytrum repens }\end{array}$ & $\begin{array}{l}\text { Poaceae } \\
\text { Leguminosae } \\
\text { Poaceae } \\
\text { Asteraceae } \\
\text { Portulacacea } \\
\text { Euphorbiaceae } \\
\text { Nyctaginaceae } \\
\text { Asteraceae } \\
\text { Poaceae } \\
\text { Poaceae }\end{array}$ & $\begin{array}{l}\text { Perennial grass } \\
\text { Perennial broadleaf } \\
\text { Annual grass } \\
\text { Annual broadleaf } \\
\text { Perennial broadleaf } \\
\text { Annual broadleaf } \\
\text { Perennial broadleaf } \\
\text { Annual broadleaf } \\
\text { Annual grass } \\
\text { Annual grass }\end{array}$ \\
\hline Manual Weeding & $\begin{array}{l}\text { Tridax procumbens } \\
\text { Syndrella nodiflora } \\
\text { Boerhavia erecta } \\
\text { Talinum triangulare } \\
\text { Panicum maximum }\end{array}$ & $\begin{array}{l}\text { Asteraceae } \\
\text { Asteraceae } \\
\text { Nyctaginaceae } \\
\text { Portulacacea } \\
\text { Poaceae }\end{array}$ & $\begin{array}{l}\text { Annual broadleaf } \\
\text { Annual broadleaf } \\
\text { Perennial broadleaf } \\
\text { Perennial broadleaf } \\
\text { Perennial grass }\end{array}$ \\
\hline Synthetic herbicide & $\begin{array}{l}\text { Panicum maximum } \\
\text { Paspalum conjugatum }\end{array}$ & $\begin{array}{l}\text { Poaceae } \\
\text { Poaceae }\end{array}$ & $\begin{array}{l}\text { Perennial grass } \\
\text { Perennial grass }\end{array}$ \\
\hline $\begin{array}{l}\text { Plastic mulch + } \\
\text { Manual Weeding }\end{array}$ & $\begin{array}{l}\text { Syndrella nodiflora } \\
\text { Tridax procumbens } \\
\text { Panicum maximum }\end{array}$ & $\begin{array}{l}\text { Asteraceae } \\
\text { Asteraceae } \\
\text { Poaceae }\end{array}$ & $\begin{array}{l}\text { Annual broadleaf } \\
\text { Annual broadleaf } \\
\text { Perennial grass }\end{array}$ \\
\hline $\begin{array}{l}\text { Plastic Mulch + Synthetic } \\
\text { herbicide }\end{array}$ & $\begin{array}{l}\text { Panicum maximum } \\
\text { Paspalum conjugatum }\end{array}$ & $\begin{array}{l}\text { Poaceae } \\
\text { Poaceae }\end{array}$ & $\begin{array}{l}\text { Perennial grass } \\
\text { Perennial grass }\end{array}$ \\
\hline
\end{tabular}




\section{Sarkodie-Addo et al.}

plots (without plastic mulch) and the synthetic herbicide only treated plots. This was unexpected considering the difference between their corresponding mulched plots. This raises questions on the persistence of the pre-emergent herbicide on un-mulched plots, an indication that herbicides are more effective in pineapple weed management in the presence of plastic mulch.

Weed diversity was highest on the weedy check followed by the two treatments with manual weeding (Table 2). This indicates that the weed management methods had an effect on the range of weeds. The two manual weeding treatments may have reduced the diversity of weeds by uprooting and exposing the weeds to sun burn, preventing regeneration and whiles those with the synthetic herbicides may have killed the weeds to prevent regeneration and again prevented the re-germination of the weed species recorded in the weedy check. The few grasses which could germinate after some time may have had more resistance to the herbicides than the other weeds which could not. The greater numbers of the Poaceae and the Asteraceae families might probably be as a result of the abundance of the two families in the area, compared to the other weed families.

Table 3 shows efficiencies of the weed management methods evaluated over the weedy check. The best method was the plastic mulch + synthetic herbicide with the manual weeding being the least efficient. The efficiency of the plastic mulch+synthetic herbicide treatment was over $30 \%$ and $10 \%$ respectively, over those of the manual weeding and synthetic herbicide treatment. The results indicate that in pineapple weed control the use of herbicide alone is not a very effective practice and that a farmer would be better off by combining it with plastic mulch. Furthermore their ability to reduce weed diversity may imply loss of biodiversity which will not auger well for sustainable agriculture and the environment.

Table 2: Effect of weed management on number of weeds and dry weight and number of weed species in the pineapple fields

\begin{tabular}{|c|c|c|c|c|c|c|}
\hline \multirow{2}{*}{$\begin{array}{l}\text { TREATMENTS } \\
\text { Weedy Check }\end{array}$} & \multicolumn{2}{|c|}{$\begin{array}{c}\text { Mean number of } \\
\text { weeds } / \mathbf{m}^{2}\end{array}$} & \multicolumn{2}{|c|}{$\begin{array}{c}\text { Mean dry weight of } \\
\text { weeds }\left(\mathrm{g} / \mathrm{m}^{2}\right)\end{array}$} & \multicolumn{2}{|c|}{ Number of weed species } \\
\hline & $3.5 \mathrm{a}$ & $(11.8)^{*}$ & $3.47 \mathrm{a}$ & $(3013.0)$ & $2.8 \mathrm{a}$ & $(7.1)$ \\
\hline Manual Weed & $2.03 b$ & (3.6) & $3.25 b$ & (1778.3) & $2.3 b$ & $(4.8)$ \\
\hline Synthetic herbicide & $1.91 b c$ & $(3.1)$ & $2.66 \mathrm{~d}$ & $(457.1)$ & $1.8 \mathrm{c}$ & $(2.8)$ \\
\hline $\begin{array}{l}\text { Plastic mulch }+ \\
\text { Manual Weeding }\end{array}$ & $1.79 \mathrm{c}$ & (2.3) & $2.86 \mathrm{c}$ & (719.5) & $2.2 \mathrm{~b}$ & $(4.6)$ \\
\hline $\begin{array}{l}\text { Plastic Mulch + } \\
\text { Synthetic herbicide }\end{array}$ & $1.27 \mathrm{~d}$ & $(1.1)$ & $2.25 \mathrm{e}$ & $(175.8)$ & $1.3 \mathrm{~d}$ & $(1.2)$ \\
\hline s. e. d. & 0.08 & & 0.04 & & 0.19 & \\
\hline CV $(\%)$ & 36.78 & & 15.43 & & 28.54 & \\
\hline
\end{tabular}

Means followed by the different letters within a column in all tables are significantly different at the $5 \%$ level according to DMRT. *Back transformed means are presented in brackets 
Table 3: Efficiency of weed management methods over control

\begin{tabular}{lc}
\hline TREATMENTS & Weed control efficiency over weedy check $(\%)$ \\
\hline Weedy Check & - \\
Manual Weed & 69.2 \\
Synthetic herbicide & 73.4 \\
Plastic mulch + & \\
Manual Weeding & 80.2 \\
Plastic Mulch + & \\
Synthetic herbicide & 90.6 \\
\hline
\end{tabular}

Table 4: Mean number of mealybugs per fruit and root zone of pineapple plants

\begin{tabular}{lcccc}
\hline TREATMENTS & \multicolumn{2}{c}{$\begin{array}{c}\text { Mean number of mealy- } \\
\text { bugs per fruit at harvest }\end{array}$} & $\begin{array}{c}\text { Mean number of mealybugs in root- } \\
\text { zone at harvest }\end{array}$ \\
\hline Weedy Check & $8.9 \mathrm{a}$ & $(78.9)$ & $6.04 \mathrm{a}$ & $(35.98)$ \\
Manual Weed & $7.1 \mathrm{~b}$ & $(50.3)$ & $5.94 \mathrm{a}$ & $(34.78)$ \\
Synthetic herbicide & $7.3 \mathrm{~b}$ & $(53.0)$ & $5.58 \mathrm{a}$ & $(30.64)$ \\
$\begin{array}{l}\text { Plastic mulch + } \\
\text { Manual Weeding }\end{array}$ & $7.6 \mathrm{~b}$ & $(57.6)$ & $5.96 \mathrm{a}$ & \\
& & & & \\
Plastic Mulch + & & & & \\
Synthetic herbicide & $7.5 \mathrm{~b}$ & $(55.2)$ & $6.31 \mathrm{a}$ & \\
& & & $\mathbf{0 . 4 9}$ & \\
S. e. d. & $\mathbf{0 . 2 4}$ & & $\mathbf{1 1 . 5 4}$ \\
CV $(\boldsymbol{\%})$ & $\mathbf{9 . 8 9}$ & & \\
\hline
\end{tabular}

Back transformed means are presented in brackets

Weed management and mealybug populations

Table 4 shows the effect of the various weed management on mealybug population. Treatment effect were similar, but they all supported significant least mealybug population on the fruits than the weedy check. Mealybug populations in the root zone, however, were statistically similar among all treatments.
The prime importance of the pineapple mealybug, D. brevipes (Hemiptera: Pseudococcidae) on the pineapple farms lies in the role it plays in causing the pineapple mealybug wilt, the reduction of market value due to its presence and the rejection of fruits meant for export (and possible ban on export) if found on them. Its control is thus of much importance. The results show that weed management significantly 


\section{Sarkodie-Addo et al.}

reduced the mealybug populations on the fruits over the weedy check. Two reasons may account for this. First, weed management exposes the mealybugs on the fruits to their natural enemies, making it difficult for them to increase in population as compared to the weedy check which provided secret hiding place for the mealybugs. Secondly, the large weed biomass in the weedy check may have provided a good habitation for the tending ants of the mealybugs and in so doing ensured the proliferation of the mealybugs since the ant population is highly correlated with the mealybug populations.

No significant differences were observed in the mealybug populations in the root zones (leaf bases and roots) among the treatments. This implies that weed management methods did not impact on the mealybug populations in the root zone. Possibly, the habitation of root zone by mealybugs is largely affected by soil conditions rather than above ground conditions, an indication that weed management studied did not affect soil conditions enough to significantly reduce or increase the mealybug populations. By extension, the plastic mulch also did not impact on the population of the mealybugs in the root zone. This was rather not expected because it was thought that the plastic mulch could provide a safe hiding place for the mealybugs to proliferate, but it turned out not to be so.

Economic analysis of production under various weed management methods

Table 5 shows the profitability of production under various weed management systems. The results presented assumed all other expenses, apart from weed management, equal. It is obvious that the most profitable is to produce with the plastic mulch + synthetic herbicide system. However, the initial capital may not be available and the abuse in the use of synthetic herbicides may also impact negatively on the environment, for which reasons, the farmer may want to opt for another method. The weed management methods which include manual weeding, spread the cost of weed management over time, making it more flexible, however the farmer pays more for weed control by the end of production. In whichever case, the use of plastic mulch is highly important and farmers should, in the best of their interest endeavor to use it.

\section{CONCLUSIONS}

Plastic mulch + herbicide was the most effective, in the control of weeds. Weed population, weed dry weight, time of weed re-emergence and number of species emerged were all signi-

Table 5: Profitability of production under weed management methods

\begin{tabular}{lccc}
\hline TREATMENTS & $\begin{array}{c}\text { Gross Revenue } \\
(\mathbf{G H c})\end{array}$ & $\begin{array}{c}\text { Total cost } \\
(\mathbf{G H c})\end{array}$ & $\begin{array}{c}\text { Profit } \\
(\mathbf{G H c})\end{array}$ \\
\hline Weedy Check & 5535.55 & 2756 & 2779.55 \\
Manual Weed & 9068.02 & 3656 & 5412.02 \\
$\begin{array}{l}\text { Synthetic herbicide } \\
\text { Plastic mulch }+\end{array}$ & 14755.16 & 2906 & 11849.16 \\
Manual Weeding & 17129.58 & 3167 & 13962.58 \\
$\begin{array}{l}\text { Plastic Mulch + } \\
\text { Synthetic herbicide }\end{array}$ & 19706.66 & & \\
\hline
\end{tabular}


ficantly lower in this treatment. All treatments, apart from the manual weeding effectively controlled all broadleaved weeds, whilst the grass species, Panicum maximum re-emerged in all treatments. The economic analysis also showed that it was most profitable to cultivate pineapple with plastic mulch + synthetic herbicides but as well, the most capital intensive. All weed management methods reduced significantly mealybug populations on the fruits of pineapples, but not on the roots. Finally, the study showed that the most economic method of weed management in pineapple fields was the plastic mulch + herbicide method.

\section{REFERENCES}

Akobundu, I. O. (1987). Weed Science in the Tropics: Principles and Practices. New York: John Wiley and Sons

Anonymous (2005). Diuron. Pesticide News. 67:20-21

Food and Agriculture Organization, (1990). Soil map of Ghana. Retrieved from h t t p : / / 74.54 .19 .227 / G H P / i mg/ pics/70078697.jpg
Mau, R. F. L. and Kessing, J. L. M. (2007). Dysmicoccus brevipes (Cockerell).

Crop Knowledge Master. Retrieved from http://www.extento.hawaii.edu/kbase/crop/ Type/d_brevip.htm

Morton, J. (1987). Pineapple. In Fruits of Warm Climates. Julia F. Morton, Miami, FL. p 18-28.

Naylor, R. E. L. (ed.). (2002). Weed management handbook. Oxford: Blackwell Publishers

Rohrbach, K. G., Beardsley, J. W., German, T. L., Relmer, V. L. and Sanford, W. G. (1988). Mealybug wilt, mealybugs and ants on pineapples. Plant Disease, 72 (7): 558-565

Statistics, Research and Information Directorate (2007). Annual sample survey of agriculture, Ghana, 2006:Regional and District cropped area, yield and production statistics. Accra: Ministry of Food and Agriculture. 